
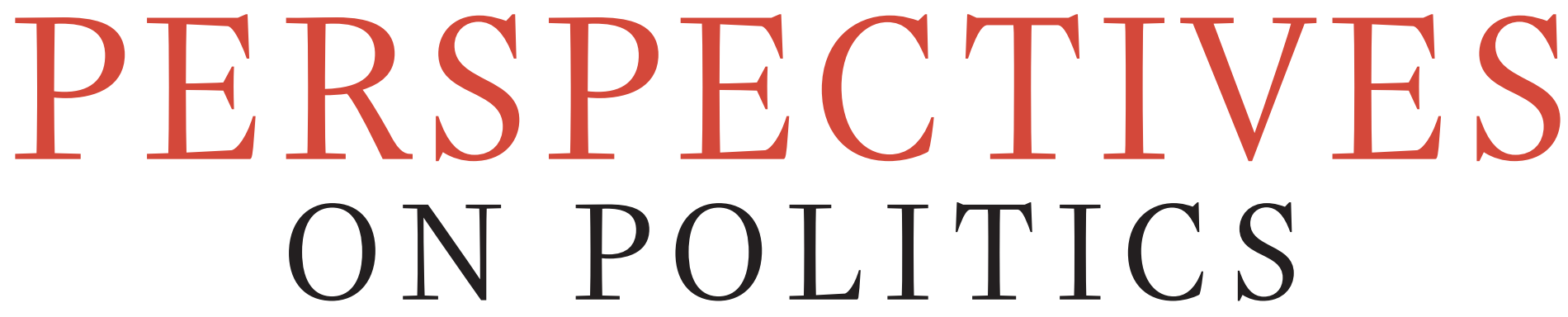

A Political Science Public Sphere March 2012, Volume 10, Number 1

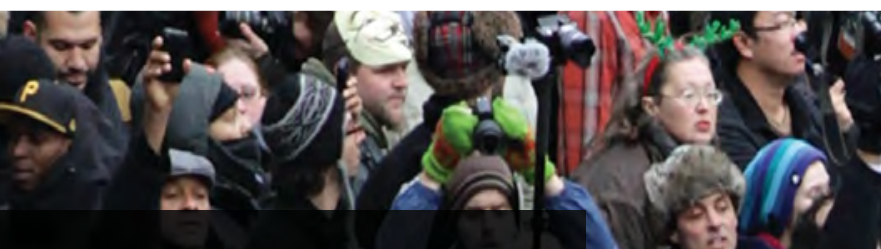

Participator
Democracy

Revisited

Carole Pateman 


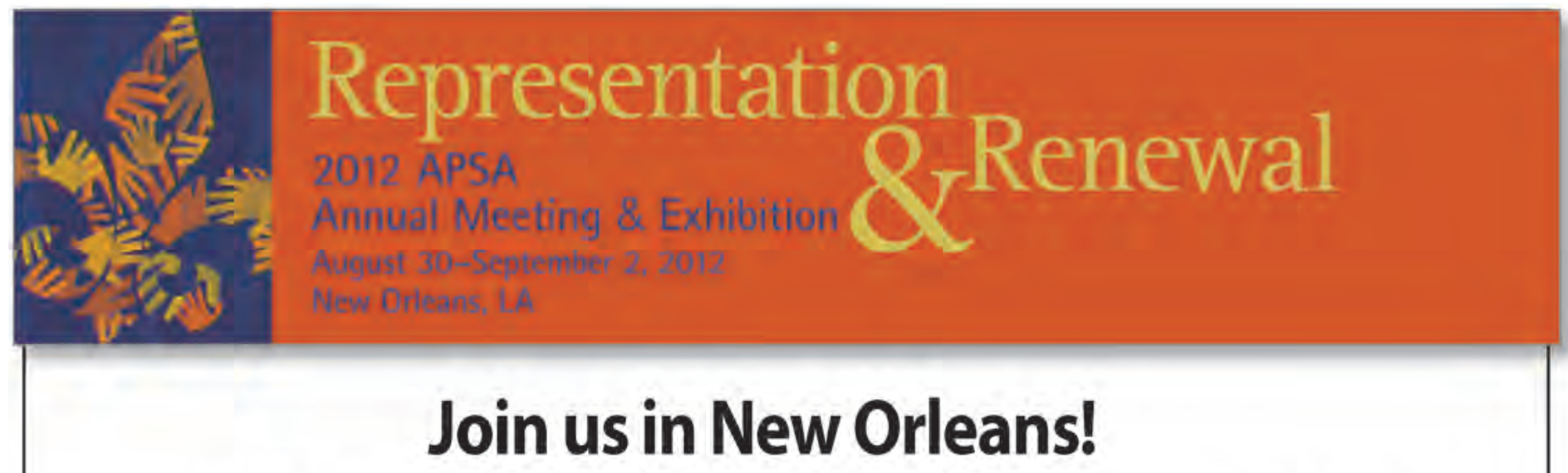

Join APSA in New Orleans to address the latest scholarship in political science and to explore this year's theme "Representation and Renewal." APSA and the 2012 Program Chairs Lynn Vavreck, University of California, Los Angeles, and John M. Carey, Dartmouth College, encourage you to attend the 2012 APSA Annual Meeting in New Orleans, Louisiana.

\section{BE PART OF THE CONVERSATION}

Nearly 7,000 political scientists will gather to exchange ideas. Take advantage of more than 800 sessions per day. To learn more about the 2012 Annual Meeting, read the complete theme statement, and view the program, visit www.apsanet.org/2012.

\section{See you in August! www.apsanet.org/2012}

\section{Future APSA Conferences}

\section{APSA Annual Meeting \& Exhibition}

August 29-September 1, 2013

August 28-31, 2014

September 3-6, 2015

September 1-4, 2016
Chicago, IL (Hyatt/Sheraton)

Washington, D.C. (Omni/Hilton/Marriott)

San Francisco, CA (Hilton/Hotel Nikko/Parc 55)

Philadelphia, PA (Pennsylvania Conv Ctr/Philadelphia Marriott

\section{APSA Teaching \& Learning Conference}

For information about APSA conferences and events www.apsanet.org/conferences

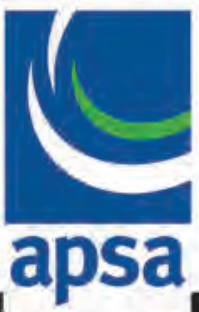




\section{Perspectives on Politics}

March 2012/Vol. 10, No. 1 | American Political Science Association

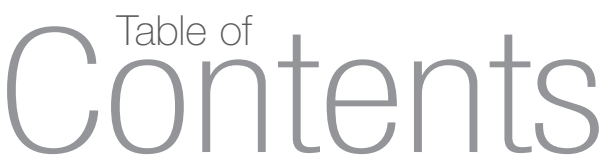

\section{Editor's Introduction}

1 Occupations, Preoccupations, and Political Science

Jeffrey C. Isaac

\section{Presidential Address}

7 Participatory Democracy Revisited

Carole Pateman

\section{Articles}

21 Judgment and Measurement in Political Science Andreas Schedler

37 Unwritten Rules: Informal Institutions in Established Democracies

Julia R. Azari and Jennifer K. Smith

57 What Happened to Post-Partisanship? Barack Obama and the New American Party System Sidney M. Milkis, Jesse H. Rhodes, and Emily J. Charnock

77 Is There a Trade-off between Multiculturalism and Socio-Political Integration? Policy Regimes and Immigrant Incorporation in Comparative Perspective

Matthew Wright and Irene Bloemraad

\section{Review Essay}

97 Is Islam Bad for Business?

Jack A. Goldstone

\section{Review Symposia}

103 Religion and American Public Life

A Discussion of American Grace: How Religion Divides and Unites Us.

By Robert D. Putnam and David E. Campbell

Laura R. Olson

Jean Bethke Elshtain

David Sehat

Jon A. Shields

Cover Art: NYPD officers push a fence back against activists as they try and gain entrance to the private park owned by Trinity Church next to Duarte Square at Sixth Avenue and Canal Street on December 17, 2011 in New York City. Activists marked the three month anniversary of the Occupy Wall Street movement with speeches and performances in Duarte Square. (Photo by Michael Bocchieri/Getty Images) 
119 Teachers Unions and Public Education

A Discussion of Special Interest: Teachers Unions and America's Public Schools

By Terry M. Moe

Martin R. West

Richard M. Battistoni

Paul Frymer

Leo Casey

Peter A. Swenson

M. Victoria Murillo

\section{Critical Dialogues}

137 Reviews and Responses

John P. McCormick

Machiavellian Democracy

Jeffrey A. Winters

Oligarchy

145 Reviews and Responses

Terrence L. Chapman

Securing Approval: Domestic Politics

Thomas Knecht

and Multilateral Authorization for War

Paying Attention to Foreign Affairs: How Public

Opinion Affects Presidential Decision Making

\section{Book Reviews}

\section{RELIGION AND POLITICS}

151 Thomas Banchoff and Robert Wuthnow, eds. Religion and the Global Politics of Human Rights.

Review by Bryan T. McGraw

Ronald Beiner, Civil Religion: A Dialogue in the History of Political Philosophy.

Review by Duncan Kelly

Nachman Ben-Yehuda, Theocratic Democracy: The Social Construction of Religious and Secular Extremism. Review by Myron J. Aronoff

Michael Berkman and Eric Plutzer, Evolution, Creationism, and the Battle to Control America's Classrooms. Review by A. Maurits van der Veen

Katerina Delacoura, Islamist Terrorism and Democracy in the Middle East. Review by Ani Sarkissian

Jack Snyder, ed. Religion and International Relations Theory. Review by Nukhet A. Sandal

Monica Duffy Toft, Daniel Philpott, and Timothy Samuel Shah, God's Century: Resurgent Religion and Global Politics.

Andrew Phillips, Religion, War and Empire: The Transformation of International Orders. Review by Philip S. Gorski

Emile Lester, Teaching about Religions: A Democratic Approach for Public Schools. Review by Sigal R. Ben-Porath

Bryan T. McGraw, Faith in Politics: Religion and Liberal Democracy. Review by Laura R. Olson

Walter A. Skya, Japan's Holy War: The Ideology of Radical Shintō Ultranationalism. Review by Eiko Maruko Siniawer

Frédéric Volpi, Political Islam Observed: Disciplinary Perspectives.

Review by Jillian Schwedler

\section{POLITICAL THEORY}

166 Jason Brennan, The Ethics of Voting. Review by Kasper Lippert-Rasmussen

167 Douglas John Casson, Liberating Judgment: Fanatics, Skeptics, and John Locke's Politics of Probability. Review by Kristy M. King 
Kathy E. Ferguson, Emma Goldman: Political Thinking in the Streets. Review by Loralea Michaelis

David J. Gauthier, Martin Heidegger, Emmanuel Levinas, and the Politics of Dwelling. Review by Matthew C. Weidenfeld

Dick Howard, The Primacy of the Political: A History of Political Thought from the Greeks to the French and American Revolutions. Review by Hauke Brunkhorst

Duncan Kelly, The Propriety of Liberty: Persons, Passions and Judgement in Modern Political Thought. Review by Graeme Garrard

Michael Saward, The Representative Claim. Review by Horacio Spector

Lawrence A. Scaff, Max Weber in America. Review by Peter Breiner

Stuart A. Scheingold, The Political Novel: Re-Imagining the Twentieth Century. Review by Simon Stow

Peter Stone, The Luck of the Draw: The Role of Lotteries in Decision Making. Review by Adrian Vermeule

\section{AMERICAN POLITICS}

181 Naomi Cahn and June Carbone, Red Families v. Blue Families: Legal Polarization and the Creation of Culture. Review by Ruy Teixeira

David T. Courtwright, No Right Turn: Conservative Politics in a Liberal America. Review by Brian J. Glenn

Kate Kenski, Bruce W. Hardy, and Kathleen Hall Jamieson, The Obama Victory: How Media, Money, and Message Shaped the 2008 Election. Review by Michael Tesler

Regina G. Lawrence and Melody Rose, Hillary Clinton's Race for the White House: Gender Politics and the Media on the Campaign Trail. Review by Tracy Osborn

Jeffery J. Mondak, Personality and the Foundations of Political Behavior. Review by Stanley Feldman

John T. Parry, Understanding Torture: Law, Violence, and Political Identity. Review by Tracy L. R. Lightcap

Lori Peek, Behind the Backlash: Muslim Americans after 9/11. Review by Sally Howell

Ronald Schmidt, Sr., Yvette M. Alex-Assensoh, Andrew L. Aoki, and Rodney E. Hero, Newcomers, Outsiders, and Insiders: Immigrants and American Racial Politics in the Early Twenty-first Century. Review by Els de Graauw

Dorothee Schneider, Crossing Borders: Migration and Citizenship in the Twentieth-Century United States. Review by Philip E. Wolgin

Mark Lawrence Schrad, The Political Power of Bad Ideas: Networks, Institutions, and the Global Prohibition Wave. Review by Bryan D. Jones

Patrick Sellers, Cycles of Spin: Strategic Communication in the U.S. Congress. Review by Michael J. Ensley

Todd C. Shaw, Now Is the Time! Detroit Black Politics and Grassroots Activism. Review by James Lance Taylor

Tracy Sulkin, The Legislative Legacy of Congressional Campaigns. Review by Laurel Harbridge

\section{COMPARATIVE POLITICS}

198 Mark W. Frazier, Socialist Insecurity: Pensions and the Politics of Uneven Development in China.

Scott Wilson, Remade in China: Foreign Investors and Institutional Change in China. Review by Shaun Breslin

Rebecca Kolins Givan, Kenneth M. Roberts, and Sarah A. Soule, eds. The Diffusion of Social Movements: Actors, Mechanisms, and Political Effects.

Review by David S. Meyer

201 Hank Johnston, States and Social Movements.

Elke Zuern, The Politics of Necessity: Community Organizing and Democracy in South Africa. Review by Deva Woodly

Marlène Laruelle, Russian Eurasianism: An Ideology of Empire. Review by Mark Kramer 
205 Samer Soliman, The Autumn of Dictatorship: Fiscal Crisis and Political Change in Egypt under Mubarak. Review by Lisa Blaydes

206 Jeffrey Stacey, Integrating Europe: Informal Politics and Institutional Change. Review by John McCormick

207 Margit Tavits, Presidents in Parliamentary Systems: Do Direct Elections Matter? Review by Robert Elgie

209 Alan Ware, The Dynamics of Two-Party Politics. Party Structure and the Management of Competition. Review by Herbert Kitschelt

\section{INTERNATIONAL RELATIONS}

210 Alison Brysk, Global Good Samaritans: Human Rights as Foreign Policy. Review by Anthony F. Lang, Jr.

212 Daniel W. Drezner, Theories of International Politics and Zombies. Review by Bruce W. Jentleson

213 Rita Floyd, Security and the Environment: Securitisation Theory and US Environmental Security Policy. Review by Jaap de Wilde

214 Hent Kalmo and Quentin Skinner, eds. Sovereignty in Fragments: The Past, Present and Future of a Contested Concept. Review by Turan Kayaoğlu

Devesh Kapur, Diaspora Development and Democracy: The Domestic Impact of International Migration from India. Review by Gabriel (Gabi) Sheffer

217 Elizabeth Kier and Ronald R. Krebs, eds. In War's Wake: International Conflict and the Fate of Liberal Democracy.

Douglas L. Kriner and Francis X. Shen, The Casualty Gap: The Causes and Consequences of American Wartime Inequalities. Review by Giacomo Chiozza

Charles Kupchan, How Enemies Become Friends: The Sources of Stable Peace. Review by Benjamin Miller

George Lawson, Chris Armbruster, and Michael Cox, eds. The Global 1989: Continuity and Change in World Politics. Review by M. E. Sarotte

Siniša Malešević, The Sociology of War and Violence. Review by Erica Chenoweth

Zeev Maoz, Networks of Nations: The Evolution, Structure, and Impact of International Networks, $1816-2001$. Review by Michael D. Ward

Ernest R. May, Richard Rosecrance, and Zara Steiner, eds. History and Neorealism. Review by Jeffrey W. Taliaferro

227 Alex Mintz and Karl DeRouen, Jr., Understanding Foreign Policy Decision Making.

Mark Schafer and Scott Crichlow, Groupthink Versus High-Quality Decision Making in International Relations. Review by Deborah Welch Larson

Peter Trubowitz, Politics and Strategy: Partisan Ambition and American Statecraft. Review by Jonathan Kirshner

Ruben Zaiotti, Cultures of Border Control: Schengen and the Evolution of European Frontiers. Review by Martin A. Schain 


\section{What's New in Political Science?}

\section{Ideology in America}

Christopher Ellis and

James Stimson

\$99.00: Hb: 978-1-107-01903-4: 216 pp.

\$26.99: Pb: 978-1-107-68741-7

\section{American Political Economy in Global Perspective \\ Harold L. Wilensky \\ \$95.00: Hb: 978-1-107-01809-9: $376 \mathrm{pp}$ \\ \$34.99: Pb: 978-1-107-63895-2}

\section{Arms and the University}

Military Presence and the Civic Education of Non-Military Students

Donald Alexander Downs and Ilia Murtazashvili

\$99.00: Hb: 978-0-521-19232-3: 458 pp. \$34.99: Pb: 978-0-521-15670-7

Latinos in the New Millennium An Almanac of Opinion, Behavior, and Policy Preferences

Luis R. Fraga, Rodney E. Hero, John A. Garcia, Michael Jones-Correa, Valerie Martinez-Ebers, and Gary M. Segura

\$99.00: Hb: 978-1-107-01722-1: 470 pp. \$36.99: Pb: 978-1-107-63873-0

\section{Cambridge Studies in Contentious Politics}

Putting Social Movements in their Place

Explaining Opposition to Energy Projects in the United States, 2000-2005

Doug McAdam and

Hilary Boudet

\$99.00: Hb: 978-1-107-02066-5: $208 \mathrm{pp}$.

\$27.99: Pb: 978-1-107-65031-2

The Global Right Wing and the Clash of World Politics Clifford Bob

\$95.00: Hb: 978-0-521-19381-8: $240 \mathrm{pp}$. \$26.99: Pb: 978-0-521-14544-2

\section{Strangers at the Gates}

Movements and States in Contentious Politics

Sidney Tarrow

\$95.00: Hb: 978-1-107-00938-7: 288 pp.

\$29.99: Pb: 978-1-107-40201-0

\section{Achieving Nuclear Ambitions}

Scientists, Politicians and Proliferation

Jacques E. C. Hymans

\$95.00: Hb: 978-0-521-76700-2: $328 \mathrm{pp}$.

\$32.99: Pb: 978-0-521-13225-1

\section{Securitizing Islam}

Identity and the Search for Security

Stuart Croft

\$95.00: Hb: 978-1-107-02046-7: $288 \mathrm{pp}$

\$34.99: Pb: 978-1-107-63286-8

Trust in International Cooperation International Security Institutions, Domestic Politics and American Multilateralism

\section{Brian C. Rathbun}

Cambridge Studies in International Relations

\$95.00: Hb: 978-1-107-01471-8: $280 \mathrm{pp}$.

\$32.99: Pb: 978-1-107-60376-9

The Credibility of Transnational NGOs When Virtue is Not Enough

Edited by Peter A. Gourevitch,

David A. Lake, and Janice Gross Stein

\$95.00: Hb: 978-1-107-01804-4: 246 pp.

\$32.99: Pb: 978-1-107-65169-2

\section{Global Crises and the Crisis of} Global Leadership

\section{Edited by Stephen Gill}

\$95.00: Hb: 978-1-107-01478-7: $316 \mathrm{pp}$.

\$30.99: Pb: 978-1-107-67496-7

\section{Textbook}

Global Distributive Justice

An Introduction

Chris Armstrong

\$90.00: Hb: 978-1-107-00892-2: 276 pp.

\$32.99: Pb: 978-1-107-40140-2

The Rise of Ethnic Politics in Latin America

Raúl L. Madrid

\$95.00: Hb: 978-0-521-19559-1: 248 pp. \$28.99: Pb: 978-0-521-15325-6

Communication,
Society and Politics
Collective Action in
Organizations
Interaction and Engagement
in an Era of Technological Change
Bruce Bimber, Andrew Flanagin, and
Cynthia Stohl
\$99.00: Hb: 978-0-521-19172-2: 208 pp.
\$29.99: Pb: 978-0-521-13963-2
Digital Media and Political
Engagement Worldwide
A Comparative Study
Edited by Eva Anduiza,
Michael James Jensen, and
Laia Jorba
\$95.00: Hb: 978-1-107-02142-6: $296 \mathrm{pp}$.
\$29.99: Pb: $978-1-107-66849-2$

\section{Building Democracy in Japan}

Mary Alice Haddad

\$99.00: Hb: 978-1-107-01407-7: $272 \mathrm{pp}$.

\$27.99: Pb: 978-1-107-60169-7

\section{Chinese and Indian}

Strategic Behavior

Growing Power and Alarm

George J. Gilboy and

Eric Heginbotham

\$99.00: Hb: 978-1-107-02005-4: $250 \mathrm{pp}$.

\$32.99: Pb: 978-1-107-66169-1

\section{Confucianism and}

Democratization in East Asia

Doh Chull Shin

\$95.00: Hb: 978-1-107-01733-7: $382 \mathrm{pp}$.

\$28.99: Pb: 978-1-107-63178-6

\section{Second Edition}

Social Science Methodology

A Unified Framework

John Gerring

Strategies for Social Inquiry

\$99.00: Hb: 978-0-521-11504-9: 526 pp. \$38.99: Pb: 978-0-521-13277-0

Prices subject to change. 


\section{Philosophy of Perspectives on Politics}

Perspectives seeks to nurture a political science public sphere, publicizing important scholarly topics, ideas, and innovations, linking scholarly authors and readers, and promoting broad reflexive discussion among political scientists about the work that we do and why this work matters.

A full-length copy of the journal's editorial philosophy appears in Perspectives on Politics 8(1): 7-10 and also on the web at http://www.apsanet.org/ content_44375.cfm.

\section{Submission and Review}

For submission guidelines, please see http://www.apsanet.org/ content_44360.cfm.

Our editorial team discusses all submissions. Those that seem promising are evaluated by several external reviewers - with full confidentiality on both sides - and then accepted, returned for further revisions, or declined with suggestions of more appropriate venues for publication.

\section{CONTACT INFO}

Perspectives on Politics

Department of Political Science

1100 E. 7th St

Woodburn Hall 210G

Indiana University

Bloomington, IN 47405

Perspectives: perspectives@apsanet.org

Book Reviews: reviews@indiana.edu

\section{Perspectives on Politics}

Editor

Jeffrey C. Isaac, Indiana University, 2009-

Managing Editor

\section{James Moskowitz}

Book Review Managing Editor

\section{Margot Morgan}

Assistants to the Editor

\section{Hicham Bou Nassif \\ Beth Easter \\ Emily Hilty}

Adrian Florea

Associate Editors

Edwina Barvosa, University of California, Santa Barbara

Richard Battistoni, Providence College

Daniel Drezner, Fletcher School, Tufts University

Henry Farrell, George Washington University

Page Fortna, Columbia University

Marc Morjé Howard, Georgetown University

Mala Htun, University of New Mexico

Bryan Jones, University of Texas, Austin

Stathis Kalyvas, Yale University

Mary Katzenstein, Cornell University

Elizabeth S. Markovits, Mount Holyoke

Melissa Nobles, MIT

Timothy Kaufman-Osborn, Whitman College

Paul Pierson, University of California, Berkeley

James Scott, Yale University

Dara Strolovitch, University of Minnesota

Lisa Wedeen, University of Chicago
Association Office Address and Membership Information: American Political Science Association individual membership dues are as follow: Regular members with income $\$ 100,000+\$ 208: \$ 80,000-\$ 99,999, \$ 178: \$ 60,000-\$ 79,999$, $\$ 160 ; \$ 50,000-\$ 59,999, \$ 148 ; \$ 40,000-\$ 49,999, \$ 126$; less than $\$ 40,000, \$ 84$; Student members, $\$ 40$; Retired members with income $\$ 25,000+\$ 57$; Retired members with income less than $\$ 25,000, \$ 35$; Life members: $\$ 3,000$; Unemployed members: \$40; Associate member with one journal selection $\$ 52$. The amount of the dues allocated for a subscription is \$6 for an individual membership. Changes of address for mem bers should be completed online or mailed to the APSA membership office at: APSA, 1527 New Hampshire Avenue, N.W. Washington, DC 20036

Subscription, Publishing, and Advertising Office Address: Cambridge University Press, 32 Avenue of the Americas, New York, NY 10013; and (for correspondents outside the United States, Canada, and Mexico) Cambridge University Press, The Edinburgh Building, Shaftesbury Road, Cambridge CB2 8RU, England.

Subscription Information: Perspectives on Politics (ISSN 1537 5927 ) is published quarterly, in March, June, September, and December, by Cambridge University Press for the American Political Science Association. Annual institutional electronic-only subscription rate (2012) is US\$932 in the United States, Canada, and Mexico; £512 elsewhere. Annual institutional print-andelectronic subscription rate (2012) is US\$1054 in the United

States, Canada, and Mexico; $£ 573$ elsewhere. Perspectives on Politics is sold only as part of a joint subscription with the American Political Science Review and PS: Political Science \& Politics. Single part rate (2012) is US\$101 in the United States, Canada, and Mexico; £55 elsewhere. Periodicals postage rate paid at New York, NY, and additional mailing offices. Postmaster: Send address changes to Perspectives on Politics, Cambridge University Press, 100 Brook Hill Drive, West Nyack, NY 10994-2133, U.S.A

(c) the American Political Science Association 2012.

All rights reserved. No part of this publication may be reproduced, in any form or by any means, electronic, photocopying, or otherwise, without permission in writing from Cambridge University Press. Policies, request forms, and contacts are available from: http://www.cambridge.org/rights/permissions/ permission.htm

Permission to copy (for users in the U.S.A) is available from the Copyright Clearance Center, http://www.copyright.com, email: info@copyright.com

Individual Copies: Single copies of Perspectives on Politics may be purchased for $\$ 25.00$

Microfilm Editions: Microfilm editions of Perspectives on Politics are available from ProQuest Information and Learning, Ann Arbor, Ml 48106. (800) 521-0600

Advertising: Perspectives on Politics has a circulation of 16,000 . For information on advertising rates and mechanical requirements, contact Advertising Coordinator, Cambridge University Press, 32 Avenue of the Americas, New York, NY 10013. (212) 337-5000

Composition: Belian, Ltd., Dexter, MI

Printing and Distribution: The Sheridan Press, Hanover, PA 


\section{About APSA}

Founded in 1903, the American Political Science Association is the leading professional organization for the study of political science and serves more than 15,000 members in over 80 countries. With a range of programs and services for individuals, departments, and institutions, APSA brings together political scientists from all fields of inquiry, regions, and occupational endeavors within and outside academe in order to expand awareness and understanding of politics.

The direct advancement of knowledge is at the core of APSA activities. We promote scholarly communication in political science through a variety of initiatives including publishing three distinguished journals: American Political Science Review, Perspectives on Politics, and PS: Political Science and Politics.

\section{Officers}

\section{PRESIDENT}

G. Bingham Powell, Jr.

University of Rochester

\section{PRESIDENT-ELECT}

Jane Mansbridge

Harvard University

\section{VICE-PRESIDENTS}

Morris Fiorina

Stanford University

Kerstin Hamann

University of Central Florida

Niraja Gopal Jayal

Jawaharlal Nehru University

\section{SECRETARY}

Lisa L. Martin

University of Wisconsin, Madison

\section{TREASURER}

Jonathan Benjamin-Alvarado

University of Nebraska, Omaha

\section{PROGRAM CO-CHAIRS}

John M. Carey

Dartmouth College

Lynn Vavreck

University of California, Los Angeles

\section{EDITOR-IN-CHIEF, APSR}

Ronald Rogowski

University of California, Los Angeles

\section{EDITOR-IN-CHIEF,} PERSPECTIVES

Jeffrey Isaac

Indiana University

\section{EXECUTIVE DIRECTOR}

Michael Brintnall

American Political Science

Association

\section{Council}

\section{0-2012}

Jeffrey M. Berry

Tufts University

Michael C. Desch

University of Notre Dame

Christopher F. Gelpi

Duke University

Simon Hix

London School of Economics and

Political Science

Mala Htun

University of New Mexico

Anne Norton

University of Pennsylvania

Laura Katz Olson

Lehigh University

Dara Z. Strolovitch

University of Minnesota, Twin Cities

2011-2013

Paul Gronke

Reed College

Ange-Marie Hancock

University of Southern California

David A. Lake

University of Califonia, San Diego

Taeku Lee

University of Califonia, Berkeley

Kenneth J. Meier

Texas A\&M University

Kathleen Thelen

Massachusetts Institute

of Technology

Stephen M. Walt

Harvard University

Angelia R. Wilson

University of Manchester

\section{Former APSA Presidents}

Frank J. Goodnow

Albert Shaw

Frederick N. Judson

James Bryce

A. Lawrence Lowell

Woodrow Wilson

Simeon E. Baldwin

Albert Bushnell Hart

W. W. Willoughby

John Bassett Moore

Ernst Freund

Jesse Macy

Munroe Smith

Henry Jones Ford

Paul S. Reinsch

Leo S. Rowe

William A. Dunning

Harry A. Garfield

James W. Garner

Charles E. Merriam

Charles A. Beard

William Bennett Munro

Jesse S. Reeves

John A. Fairlie

Benjamin F. Shambaugh

Edward S. Corwin

William F. Willoughby

Isidor Loeb

Walter Shepard

Francis W. Coker

Arthur N. Holcombe

Thomas Reed Powell

Clarence A. Dykstra

Charles Grove Haines

Robert C. Brooks

Frederic A. Ogg

William Anderson

Robert E. Cushman

Leonard D. White

John Gaus

Walter F. Dodd

Arthur W. MacMahon

Henry R. Spencer

Quincy Wright

James K. Pollock

Peter H. Odegard

Luther Gulick

Pendleton Herring

Ralph J. Bunche

Charles McKinley

Harold D. Lasswell

E. E. Schattschneider

V. O. Key Jr.
R. Taylor Cole

Carl B. Swisher

Emmette S. Redford

Charles S. Hyneman

Carl J. Friedrich

C. Herman Pritchett

David B. Truman

Gabriel A. Almond

Robert A. Dahl

Merle Fainsod

David Easton

Karl W. Deutsc

Robert E. Lane

Heinz Eulau

Robert E. Ward

Avery Leiserson

Austin Ranney

James MacGregor Burns

Samuel H. Beer

John C. Wahlke

Leon D. Epstein

Warren E. Miller

Charles E. Lindblom

Seymour Martin Lipset

William H. Riker

Philip E. Converse

Richard F. Fenno Jr.

Aaron B. Wildavsky

Samuel P. Huntington

Kenneth N. Waltz

Lucian W. Pye

Judith N. Shklar

Theodore J. Lowi

James Q. Wilson

Lucius J. Barker

Charles O. Jones

Sidney Verba

Arend Lijphart

Elinor Ostrom

M. Kent Jennings

Matthew Holden Jr.

Robert O. Keohane

Robert Jervis

Robert D. Putnam

Theda Skocpol

Susanne Hoeber Rudolph

Margaret Levi

Ira Katznelson

Robert Axelrod

Dianne M. Pinderhughes

Peter Katzentstein

Henry E. Brady

Carole Pateman 


\section{CAMBRIDGE}

\section{JOURNALS}

\section{Published on behalf of the University of Notre Dame}
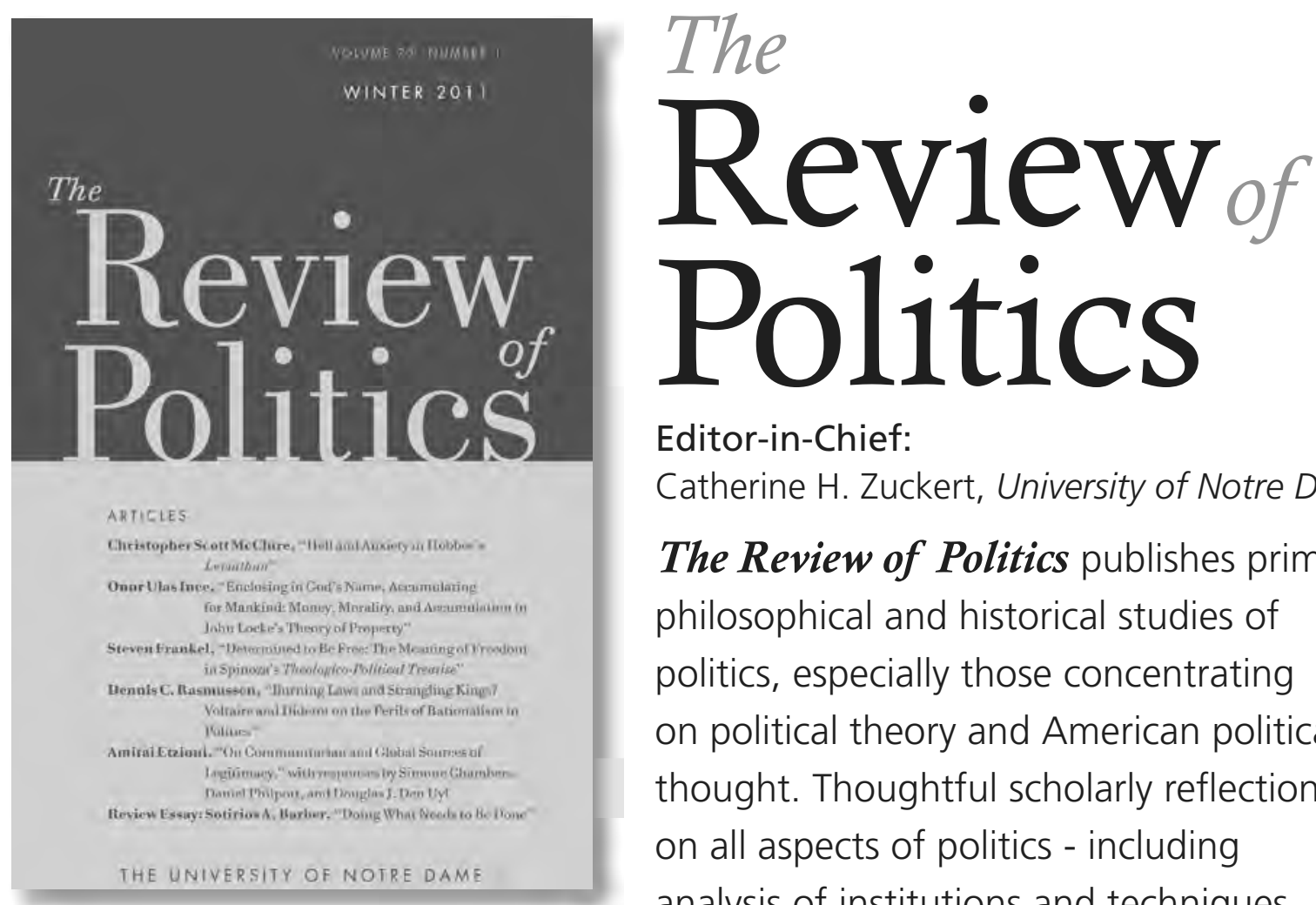

Editor-in-Chief:

Catherine H. Zuckert, University of Notre Dame

The Review of Politics publishes primarily philosophical and historical studies of politics, especially those concentrating on political theory and American political thought. Thoughtful scholarly reflections on all aspects of politics - including analysis of institutions and techniques, analysis of literary reflections on politics, political interpretations of literary works, and constitutional theory and analysis - are also welcome. Some of the first essays advocating "realism" were published in The Review, as well as articles from its opponents in international relations; both perspectives are accepted parts of the journal's coverage.

FRE E email alerts.

Keep up-to-date with new material. Sign up at: journals.cambridge.org/rop-alerts

Recommend The Review of Politics directly from its homepage FRE online access for you when your library subscribes.

\section{journals.cambridge.org/rop}

